\title{
Magnitude and variability of benthic and pelagic metabolism in a temperate coastal lagoon
}

\author{
Karen J. McGlathery ${ }^{1, *}$, Iris Cofman Anderson ${ }^{2}$, Anna Christina Tyler ${ }^{1}$ \\ ${ }^{1}$ Department of Environmental Sciences, Clark Hall, University of Virginia, Charlottesville, Virginia 22903, USA \\ ${ }^{2}$ School of Marine Science, Virginia Institute of Marine Science, College of William and Mary, Gloucester Point, \\ Virginia 23062, USA
}

\begin{abstract}
In shallow coastal systems where most of the seafloor lies within the photic zone, benthic photoautotrophy is likely to play a key role in regulating carbon and nitrogen cycling. We measured dissolved inorganic carbon exchanges in seasonal microcosm incubations to determine the relative importance of benthic (with and without macroalgae) and water column metabolism at 3 sites located along a nutrient gradient in a coastal barrier-island lagoon on the eastern shore of Virginia. When coupled with data on in situ biomass, the incubations clearly indicated a seasonality in the dominance of primary producers at the sites, with benthic primary producers being the most important early and late in the growing season and phytoplankton dominating following a mid-summer period of macroalgal decay and the release of algal-bound nutrients to the water column. The benthos was always net autotrophic, and differences in community metabolism at the 3 sites appeared to be largely due to variation in macroalgal biomass. Macroalgae accumulated to a greater extent in the mid-lagoon and accounted for up to $96 \%$ of benthic production. The water column was net heterotrophic throughout the lagoon except following the mid-summer macroalgal collapse, when phytoplankton biomass was highest at the 2 sites closest to the mainland. Benthic microalgal production also increased in importance following the macroalgal decline, suggesting that competition for light and possibly nutrients limited benthic microalgal production when macroalgal densities were high. Overall, there was a distinct seasonality in patterns of total metabolism within the bay, where all sites were net autotrophic in the spring and summer and net heterotrophic in the fall. $\mathrm{Up}$ to $8 \mathrm{~g} \mathrm{~N} \mathrm{~m}^{-2}$ accumulated in macroalgal biomass throughout spring and early summer at the mid-lagoon shoal site, slowing nutrient transport through the lagoon. Nutrient turnover rates were higher during the period when phytoplankton and benthic microalgae were the dominant primary producers. This study illustrates the functional importance of different primary producer communities to carbon metabolism and to the temporary retention of nutrients in lagoonal land-margin ecosystems.
\end{abstract}

KEY WORDS: Lagoon · Metabolism · Autotrophy $\cdot$ Heterotrophy $\cdot$ Carbon $\cdot$ Nitrogen $\cdot$ Macroalgae Phytoplankton $\cdot$ Microalgae $\cdot$ Chlorophyll

Resale or republication not permitted without written consent of the publisher

\section{INTRODUCTION}

Coastal lagoons and bays constitute a major type of land margin ecosystem on most continents, yet surprisingly little is known about the fate and transport of nutrients entering shallow lagoons compared to large,

*E-mail: kjm4k@virginia.edu deep estuaries (Boynton et al. 1996). Nutrient inputs to coastal lagoons are typically lower than to river-dominated estuaries (Nixon 1982, Boynton et al. 1996). However, changes in land use and increased human populations have also resulted in problems associated with eutrophication in coastal lagoons (Sfriso et al. 1992, Valiela et al. 1992, 1997, Boynton et al 1996). Like deep estuaries, these shallow bays and lagoons, which normally are highly productive, function as 
important buffer zones that can reduce or remove nutrients on their transit from land to sea. The impact of nutrient inputs and their retention as they pass through shallow-water systems depend on the metabolism of both autotrophs and heterotrophs within the systems as well as physical transport rates.

The benthos is a critical component of coastal lagoons and bays. In these systems, most of the seafloor lies within the photic zone, and production of seagrasses, macroalgae and benthic microalgae typically exceeds that of phytoplankton (Borum \& SandJensen 1996). Uptake and temporary retention of nutrients in plant biomass, burial of recalcitrant organic matter, and the effects of autotrophic metabolism (oxygen release and nitrogen uptake) on denitrification all influence the transport of nutrients through these shallow-water systems. Fast-growing, opportunistic macroalgae with 'boom and bust' cycles tend to proliferate where nutrient enrichment is high (e.g., McComb \& Humphries 1992, Sfriso et al. 1992, Valiela et al. 1992, 1997). At high densities, these macroalgae can function temporarily as a 'filter' by intercepting dissolved nutrient fluxes from the sediments to the overlying water, thereby reducing nutrient availability for phytoplankton growth (Thybo-Christesen \& Blackburn 1993, McGlathery et al. 1997). Release of plant-bound nutrients following senescence may subsequently stimulate phytoplankton and bacterial metabolism in the water column. Likewise, nutrient assimilation and photosynthetic oxygenation of the sediments by benthic microalgae may control nutrient fluxes at the sediment-water interface (Blackburn \& Henricksen 1983, Risgaard-Petersen et al. 1994, Reay et al. 1995, Sundbäck et al. 2000). High rates of benthic metabolism also can lead to oxygen supersaturation and to episodes of oxygen depletion throughout the water column (e.g., Sfriso et al. 1992, Valiela et al. 1992, Boynton et al. 1996).

The trophic status of the benthic or pelagic communities (measured as the difference between primary production and total respiration, i.e. autotrophy vs heterotrophy) may thus be indicative of the rates and pathways of carbon (C) and nitrogen (N) cycling in coastal systems. In addition, total metabolism integrates the benthic and pelagic components and provides useful information on the functional linkage between coastal ecosystems and adjacent systems (watershed and coastal ocean), that is, the degree to which the system is an importer or exporter of nutrients and organic matter. Most metabolism studies to date have been performed in relatively deep coastal systems where the dominant autotrophs are phytoplankton. In shallow-water systems, benthic photoautotrophy is likely to be a key driver of total metabolism (Kenney et al. 1988, D'Avanzo et al. 1996, Carmouze et al. 1998). Data on the trophic status of shallow lagoons and bays are equivocal, with some showing balanced metabolism or slight autotrophy either on a seasonal or annual basis (Reyes \& Merino 1991, D'Avanzo et al. 1996, Carmouze et al. 1998) and others indicating heterotrophy (Nowicki \& Nixon 1985, Flores-Verdugo et al. 1988). There is also evidence of both seasonal and interannual variations in patterns of autotrophy and heterotrophy (Kenney et al. 1988, Carmouze et al. 1998). Clearly, much of this variation is driven by key physical factors such as water residence time (Kenney et al. 1988, Knoppers et al. 1991) and by changes in biomass and species composition of the dominant autotrophs (Oviatt et al. 1986, Knoppers et al. 1991). Understanding the integrated response to changing activities in the watershed is key to establishing how these coastal systems function in transporting or retaining nutrient and organic matter inputs at the land-sea interface.

In this study we measured benthic and pelagic metabolism on a seasonal basis (spring, summer, fall) at 3 sites along a nutrient gradient in a shallow lagoon lying between the mainland and barrier islands on the eastern shore of Virginia. Since we were particularly interested in quantifying the relative contribution of the different autotrophic communities (phytoplankton, macroalgae, benthic microalgae) to total carbon metabolism at the 3 sites, we used microcosm incubations to distinguish metabolism of the benthic community (with and without macroalgae) from that of the water column. Several recent studies have used a similar microcosm incubation technique in shallow lagoons (Carmouze et al. 1991, 1998, Rizzo et al. 1996, Viaroli et al. 1996). The main questions we asked in this study were: (1) Are the benthic and pelagic communities at the study sites net autotrophic or net heterotrophic? (2) Are there differences across the nutrient loading gradient? This was part of a larger study aimed at understanding how the lagoon functions as a 'filter' to retain or remove reactive nitrogen in its transport across the land margin.

\section{METHODS}

Site description. Hog Island Bay is a shallow coastal lagoon $\left(100 \mathrm{~km}^{2}\right)$ on the eastern shore of Virginia and is part of the Virginia Coast Reserve (VCR) Long Term Ecological Research (LTER) Site (Fig. 1). It is bordered on the west by the Delmarva Peninsula and on the east by barrier islands, a typical feature of the Atlantic and Gulf coasts. Other than the main channel (Great Machipongo Channel) that empties into the Atlantic Ocean, the lagoon is shallow $(<1-2 \mathrm{~m}$ at mean low water [MLW]) with a semi-diurnal tidal range of 


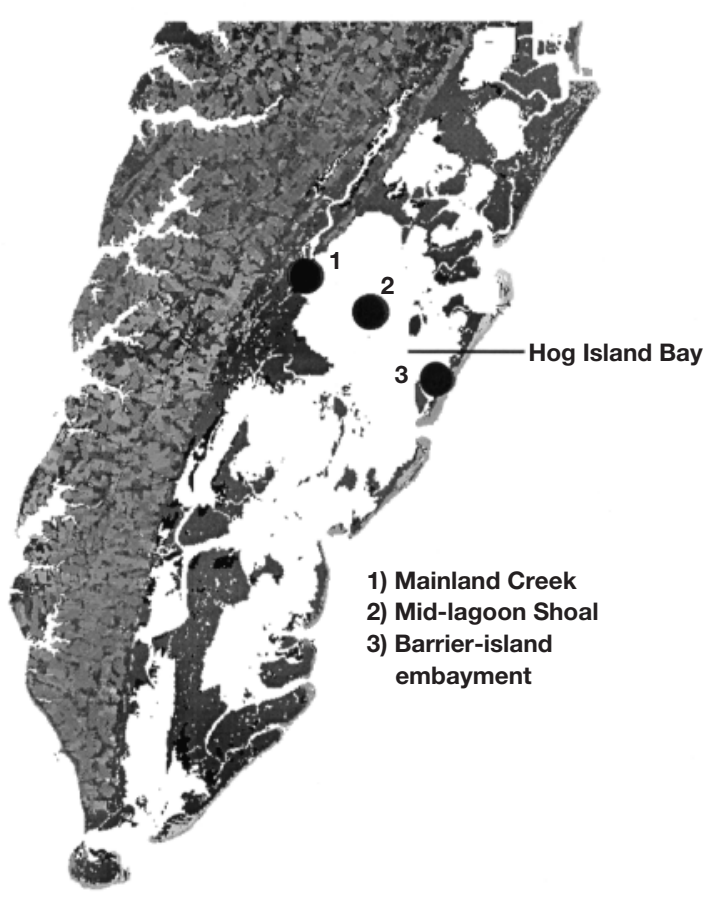

Fig. 1. Site map of Hog Island Bay, which lies within the Virginia Coast Reserve on the eastern shore of the Delmarva Peninsula. The 3 sites represent a gradient in nutrient loading across the lagoon

1.2-1.5 m. Approximately $50 \%$ of the surface area of the lagoon is $<1 \mathrm{~m}$ at MLW, and there are extensive exposed mudflats. The VCR lagoons were formerly vegetated with seagrasses, but they disappeared in the 1930s and have only recently been rediscovered in small, isolated patches. Like many coastal embayments, inputs of freshwater are relatively low and enter the lagoon primarily via groundwater. The shallow aquifer is also the main source of nutrients to the lagoon (Reay et al. 1992, Anderson et al. 1997); enrichment of groundwater is primarily the result of agricultural activities, which represent $55 \%$ of the Hog Island Bay watershed area (442 km²) (Bohlke \& Denver 1995, Hamilton \& Helsel 1995). Atmospheric inputs into the bay are probably also important (Paerl et al. 1990), although they remain to be quantified.

Three sites were sampled along a transect across Hog Island Bay from the mainland to the barrier island (Fig. 1). The sites were in the shallow ( $<1 \mathrm{~m}$ MLW) regions that dominate the lagoon and are as follows: (1) a mainland site adjacent to a fringing marsh tidal creek, 'Creek'; (2) an open-water shoal site located mid-lagoon that con- tained numerous relict oyster reefs, 'Shoal'; and (3) a back-barrier embayment site near the southern end of Hog Island, 'Hog'. Characteristics of the sites are shown in Table 1. The transect represents a gradient in nutrient loading, as reflected in the water column nutrient concentrations, in the sediment organic and nitrogen contents, and in the macroalgal tissue nitrogen content (see Table 3). The sediments ranged from fine-grained silt at the Creek site to coarse sand at the Hog site. All sites received sufficient light to support benthic photosynthesis. On an annual basis, for a mean depth of $1 \mathrm{~m}$, about 11 to $18 \%$ of incident irradiance reached the lagoon bottom. Benthic microalgae and macroalgae occurred at all sites, with Ulva lactuca and Gracilaria tikvahiae being the most abundant macroalgal taxa.

Benthic and water column metabolism. We estimated production and respiration at each site in October 1997 and May and August 1998 from changes in dissolved inorganic carbon (DIC) concentrations in microcosm incubations of: (1) water column only, (2) sediment+water column, and (3) sediment+macroalgae+water column ( $n=3$ for each treatment per site) in outdoor flowing seawater tables. The water column treatment was used both to determine water column activity and to correct the DIC measurements in the sediment and sediment+ macroalgae treatments for water column metabolism. For the sediment+macroalgae treatment, the added macroalgal biomass varied among individual cores and was equivalent to $70-200 \mathrm{gdw} \mathrm{m}^{-2}$, which is within the range of natural field densities (K.J.M. et al. unpubl. data, see Fig. 7b).

The microcosms consisted of $10 \times 30 \mathrm{~cm}$ transparent cores with magnetic stirrers attached to the clear, acrylic core tops. The stirrers mixed the water column continuously at $60 \mathrm{rpm}$ without disturbing the sediment. The cores contained $12 \mathrm{~cm}$ of sediment and $\sim 18 \mathrm{~cm}$ of overlying water. Sediment cores and Ulva lactuca were collected from each site and held

Table 1. Physical and chemical characteristics of the 3 sites in Hog Island Bay. Data are annual averages $( \pm \mathrm{SE})$ of samples taken in all 4 seasons. dw: dry weight

\begin{tabular}{|lccc|}
\hline & Creek & Shoal & Hog \\
\hline Water column nutrients $(\mu \mathrm{M})$ & & & \\
DIN & $4.4 \pm 0.9$ & $2.3 \pm 2.5$ & $1.2 \pm 0.4$ \\
DON & $15.4 \pm 1.9$ & $12.1 \pm 3.7$ & $11.8 \pm 1.6$ \\
DIP & $1.4 \pm 0.2$ & $0.8 \pm 0.1$ & $0.5 \pm 0.1$ \\
Sediment organic content $(\% \mathrm{dw})$ & $3.8 \pm 0.2$ & $2.1 \pm 0.3$ & $0.48 \pm 0.3$ \\
Sediment N content $(\% \mathrm{dw})$ & $0.11 \pm 0.00$ & $0.03 \pm 0.00$ & $0.01 \pm 0.00$ \\
Sediment molar C:N & $14.4 \pm 1.7$ & $11.76 \pm 1.4$ & $12.9 \pm 4.1$ \\
Sediment bulk density $\left(\mathrm{g} \mathrm{cm}{ }^{-3}\right)$ & $0.89 \pm 0.09$ & $1.51 \pm 0.15$ & $1.78 \pm 0.07$ \\
Light extinction, $k\left(\mathrm{~m}^{-1}\right)$ & $2.2 \pm 0.6$ & $1.9 \pm 0.8$ & $1.7 \pm 0.7$ \\
& & & \\
\hline
\end{tabular}



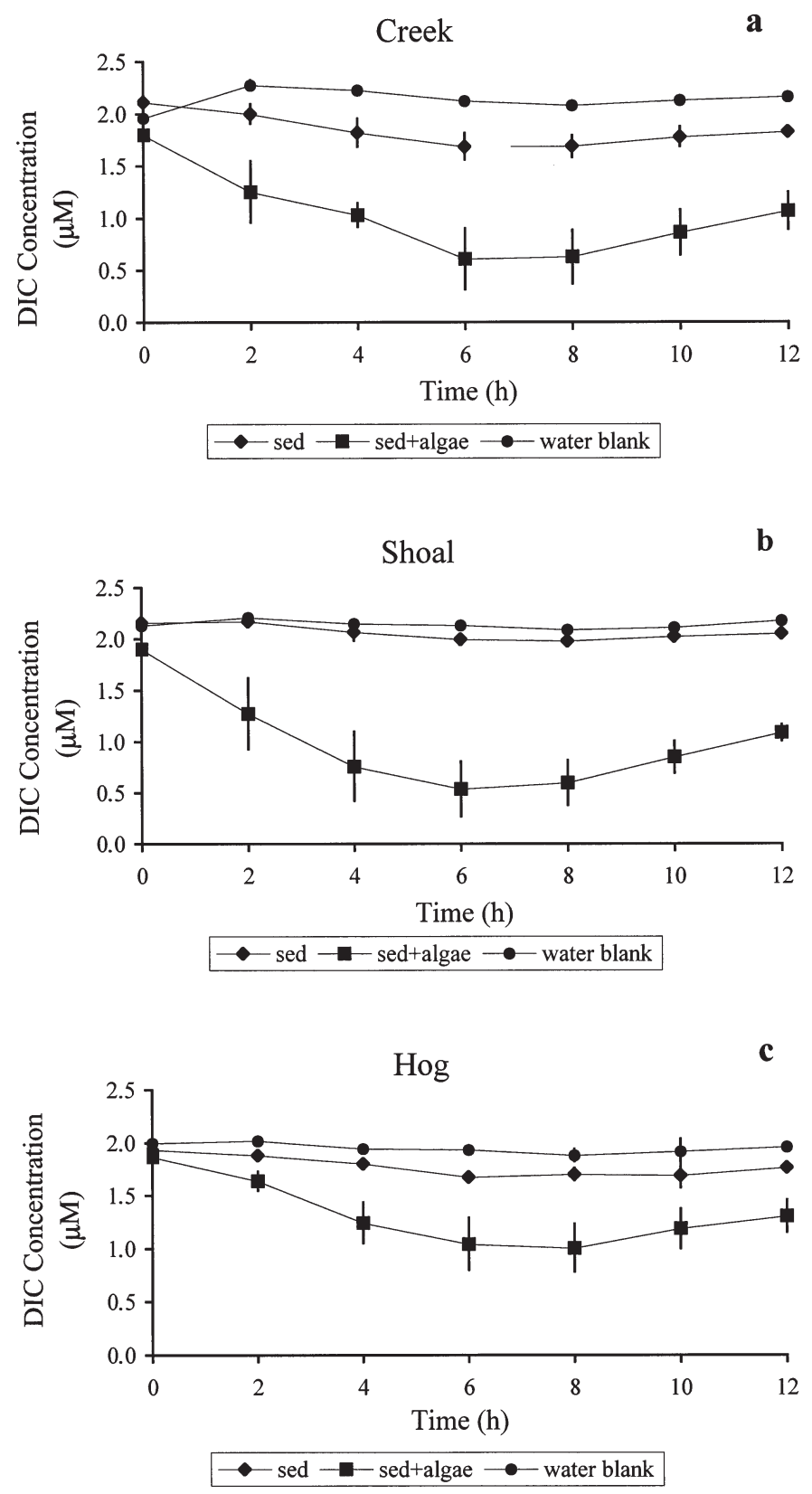

Fig. 2. Typical dissolved inorganic carbon (DIC) exchange during the microcosm incubations, showing uptake of DIC in the light during the first $6 \mathrm{~h}$ followed by DIC production in the subsequent $6 \mathrm{~h}$ dark period. The treatments are sediment, sediment+macroalgae and water blank. The slopes of the depletion and production curves indicate that DIC was not limiting to primary production during these short incubations

overnight in the seawater tables; the flowing seawater was used only to maintain in situ temperatures and did not mix with the sediment or water inside the microcosms. The incubations were initiated the following morning by replacing the overlying water of the microcosms with water collected from each site. Additional cores were set up with a water column only. Incident irradiance varied between 700 and $1200 \mu \mathrm{mol}$ photons $\mathrm{m}^{-2} \mathrm{~s}^{-1}$ during the light incubations. These levels are similar to those measured during the same months in the field (K.J.M. et al. unpubl. data), and exceed typical light saturation values for photosynthesis of both benthic microalgae (Rizzo et al. 1996) and the dominant macroalgae in Hog Island Bay (Henley \& Ramus 1989, Peckol \& Rivers 1996).

Water samples were collected at the start of the incubation and then at $2 \mathrm{~h}$ intervals during the initial $6 \mathrm{~h}$ light incubation and the subsequent $6 \mathrm{~h}$ dark incubation. All DIC samples were filtered $(0.45 \mu \mathrm{m}$, Gilman Supor) prior to storage in $13 \mathrm{ml}$ Hungate tubes (Bellco Glass Inc., Vineland, NJ), and were kept in a refrigerator until they were analyzed within 4 wk using a LiCor 6252 infra-red gas analyzer. Storage tests of estuarine water have shown that this procedure gives accurate DIC measurements for samples obtained within $6 \mathrm{wk}$ (I.C.A. unpubl. data). Production or consumption of DIC was determined from the change in concentration versus time. Our measurements showed that there was a linear change in DIC concentrations, and indicated that DIC did not become limiting to primary producers during the short incubation (Fig. 2). Changes in DIC in the light and dark incubations represent whole community metabolism, and reflect the balance between DIC consumption/production by autotrophs and production by zooplankton, benthic fauna and bacteria during the incubation period. We also measured dissolved oxygen (DO) concentrations and temperature using an Orbisphere multichannel DO detector, but found that this gave a less accurate estimate of production and respiration because the water rapidly became supersaturated and formed bubbles in the light. Nutrient fluxes across the sediment-water interface and rates of sediment $\mathrm{N}$ mineralization and immobilization were also measured and are reported by Anderson et al. (unpubl.). Changes in dissolved inorganic N (DIN) concentrations of the water column treatment showed that DIN concentrations, although low, did not become depleted during the $6 \mathrm{~h}$ light incubations due to phytoplankton uptake (Fig. 3). Thus there is no clear evidence that 'bottle effects' (i.e. separating the water column from the benthos) underestimated water column metabolism in our short-term closed incubations (Kemp \& Boynton 1980).

Sediment and water column chlorophyll a. At the end of the incubation, 1 sediment subsample from each of the cores in the sediment+water column treatments was analyzed for chlorophyll a ( $\mathrm{chl}$ a) ( $\mathrm{n}=3$ for each site). In addition, chl a was sampled in triplicate at all sites in July. The top 0 to $1 \mathrm{~cm}$ of the sediment was removed using a small corer $\left(3.98 \mathrm{~cm}^{2}\right)$ and frozen for later analysis. Chl a concentration was determined according to the protocol of Lorenzen (1967), as modi- 


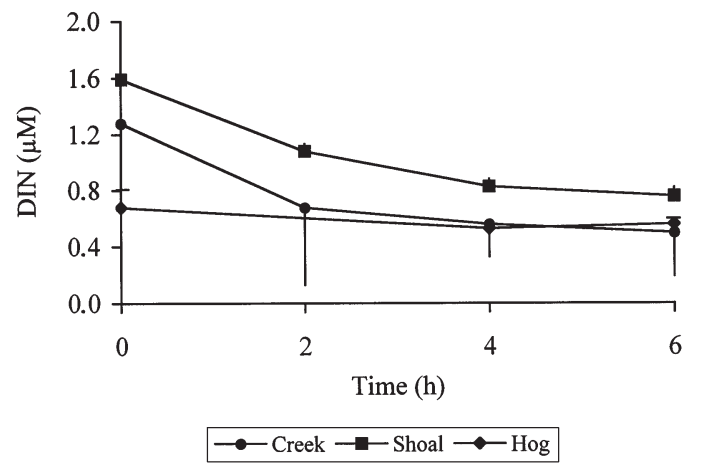

Fig. 3. Typical changes in DIN concentrations during water column incubations for the 3 sites in Hog Island Bay. The linear change in concentration indicates that DIN did not become depleted during the $6 \mathrm{~h}$ light and dark incubations

fied by Pinckney \& Zigmark (1994) to include extraction of the unground sediment sample with a solvent mixture of $45 \%$ methanol, $45 \%$ ethanol, and $10 \%$ deionized water, at $-15^{\circ} \mathrm{C}$ for $>1 \mathrm{wk}$. Water column chl a was determined in triplicate in the water collected at each site for the incubations using the method of Shoaf \& Lium (1976). Samples of $5 \mathrm{ml}$ were filtered through $\mathrm{GF} / \mathrm{F}$ filters, and the filters were extracted in a solution of $45 \%$ acetone, $45 \%$ dimethyl sulfoxide (DMSO), and $10 \%$ deionized water. Extraction took place in the dark for $24 \mathrm{~h}$.

Macroalgal biomass and elemental content. The Ulva lactuca used in the incubations was rinsed free of epiphytes with deionized water, freeze-dried and weighed. Duplicate subsamples of the tissue were ground into a fine powder with a mortar and pestle and analyzed for $\mathrm{C}$ and $\mathrm{N}$ content using a Carlo Erba NA 2500 elemental analyzer. To relate our benthic metabolism measurements from the microcosms to the natural algal densities at each site, we estimated macroalgal biomass and the amount of bare sediment area (with microalgae only) from June 1998 to June 1999 at 6 locations in the lagoon, 2 of each representing creek, midlagoon shoal, and back-barrier embayment sites. This was part of a larger effort to establish a long-term data set on primary producer biomass and distribution in the lagoon as part of the VCR LTER program (K.J.M. et al. unpubl. data). For the purposes of the present study, we assumed that the seasonal metabolism measurements could be directly related to seasonal variation in macroalgal biomass. At each location, macroalgae were collected haphazardly within a $0.15 \mathrm{~m}^{2}$ circular core cast ( $\mathrm{n}=6$ to 8 at each location, for a total of 12 to 16 replicates per site). The collected plants were sorted by species, rinsed with both lagoon water and deionized water, and carefully cleaned of attached epiphytes. Samples were then freeze-dried to a constant weight for biomass determination.
Estimating in situ benthic metabolism. Attempts to relate laboratory measurements of benthic production or nutrient uptake directly to in situ rates are problematic because of the assumption that production is constant per unit biomass. We corrected our DIC metabolism measurements from the microcosm studies for both the shading effects within the macroalgal mat (Krause-Jensen et al. 1996, Peckol \& Rivers 1996, McGlathery et al. 1997) and the macroalgal shading of the sediment surface at the measured densities of macroalgae at each site. Without accounting for these processes, we would likely overestimate benthic metabolism at our 3 sites. To make the correction, we used a straightforward procedure that involved 3 basic steps: (1) we calculated macroalgal metabolism in the microcosms by subtracting the sediment metabolism from the sediment+macroalgae treatments, (2) using field data on macroalgal biomass at each site, we factored in self-shading within the macroalgal mat to reliably estimate in situ macroalgal metabolism per $\mathrm{m}^{2}$, and (3) we estimated sediment metabolism at each site (per $\mathrm{m}^{2}$ ) based on the microcosm measurements (sediment treatment) and the shading of the sediment surface by macroalgae at each site.

We used 2 relationships in our calculations. First, we defined a function to describe the variation in benthic microalgal metabolism with varying densities of macroalgae overlying the sediment surface (Fig. 4a). When the macroalgal biomass measured at a particular location was zero, the in situ sediment metabolism was determined to equal the rates measured in the sediment microcosms for that site. At very high macroalgal densities (Fig. 4a), we assumed that complete shading of the sediment surface eliminated microalgal production, and daily DIC metabolism rates were calculated from the measured dark DIC production rates averaged over a $24 \mathrm{~h}$ period. We defined this complete shading of benthic microalgae to occur at macroalgal densities above $300 \mathrm{gdw} \mathrm{m}^{-2}$ based on the relationship found by Krause-Jensen et al. (1996) between macroalgal biomass and light attenuation. In a sensitivity analysis of our method, we found that adjusting this critical biomass to 200 or $400 \mathrm{gdw} \mathrm{m}^{-2}$ changed our results by $<3 \%$. As a first approximation, we have assumed a negative linear relationship in microalgal production with increasing macroalgal densities between these maximum and minimum values (Fig. 4a). Although vertical profiles of microalgal production with depth in bare sediments are known to be curvilinear (McIntyre et al. 1996), there is little information on how depth-integrated production varies with macroalgal coverage (Sundbäck et al. 1996). We used this linear relationship to determine sediment microalgal metabolism in the sediment+macroalgae microcosms and subtracted this 

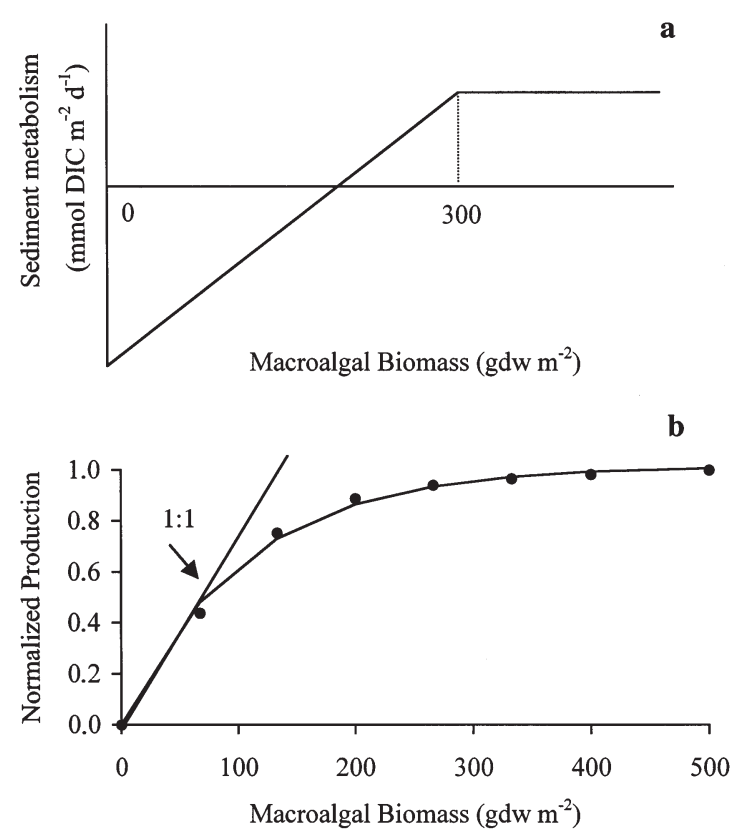

Fig. 4. Two models used to correct benthic community metabolism measurements for (a) shading of benthic microalgal production by macroalgae overlying the sediment surface and (b) self-shading within the macroalgal mat. The relationship in (b) is derived from the variation in production with depth in macroalgal mats reported in Krause-Jensen et al. (1996), and is normalized to maximum production (per unit area) at high macroalgal densities. The 1:1 line represents the production rate with no shading effects where production increases proportionately to biomass

value to obtain an estimate of macroalgal metabolism. The second relationship we used adjusted macroalgal production for self-shading within the macroalgal mat (Fig. 4b). Studies have shown the reduction of macroalgal productivity with exponentially decreasing light availability within macroalgal mats for Chaetomorpha linum (Krause-Jensen et al. 1996) and for Cladophora vagabunda and Gracilaria tikvahiae (Peckol \& Rivers 1996). Although the degree of light attenuation varies among species, the productionbiomass relationship of Krause-Jensen et al. (1996) should give a reasonable first-order estimate of in situ density-dependent production in the mixed-species mats, and is clearly more accurate than assuming constant production rates per unit biomass. A fit to the data of Krause-Jensen et al. (1996) gives $y=1-$ $\exp (-0.00804 x)\left(R^{2}=0.99\right)$ where $y$ is the production rate normalized to maximum production at high biomass and $x$ is the biomass $\left(g d w \mathrm{~m}^{-2}\right)$. Using our biomass data as input, we adjusted our production rates for self-shading. To account for differences between macroalgal densities in the microcosms and in situ densities, we determined a scaling factor:
$F=\left[1-\exp \left(-0.00804 x_{\text {field }}\right)\right] /\left[1-\exp \left(-0.00804 x_{\text {microcosm }}\right)\right]$

This factor is multiplied by the average macroalgal metabolism in the microcosms for each site to obtain an estimate of in situ macroalgal metabolism at that site. For example, if the average macroalgal biomass in the microcosms for a site was $150 \mathrm{gdw} \mathrm{m}^{-2}$ and the biomass measured in the field was $500 \mathrm{gdw} \mathrm{m}^{-2}$, the scaling factor $F$ is calculated to be 1.4 (Fig. 4 b). In other words, when the macroalgal biomass increases from 150 to $500 \mathrm{gdw} \mathrm{m}^{-2}$, the production (per unit area) will increase by a factor of 1.4. This example shows how important it is to include the effect of shading in this scaling process. If not included, scaling based on biomass alone would give a factor of 3.3 $(500 / 150)$; this is equivalent to using the 1:1 line shown in Fig. 4b. At low densities $\left(<50 \mathrm{gdw} \mathrm{m}^{-2}\right)$, the scaling factor makes little difference in the total metabolism calculation, because self-shading within the macroalgal population is of less importance and production increases proportionately with biomass. The final step in our procedure was to estimate in situ sediment metabolism. We did this in the same way as for the microcosms using the relationship shown in Fig. $4 \mathrm{a}$, but in this case we used the measured in situ macroalgal biomass to account for shading at each site.

This scaling process can be summarized by the following equation:

$$
M_{\mathrm{t}}=\left(M_{\mathrm{c}}-M_{\mathrm{s} 1}\right) F+M_{\mathrm{s} 2}
$$

where $M_{\mathrm{t}}$ is the total in situ benthic metabolism, $M_{\mathrm{c}}$ is the metabolism measured in the sediment+macroalgae microcosms, $M_{\mathrm{s} 1}$ is the sediment metabolism rate in the microcosms corrected for the shading effect of macroalgal biomass, $F$ is the scaling factor correcting for differences in the biomass in the field relative to that in the microcosms, and $M_{\mathrm{s} 2}$ is the sediment metabolism rate in situ taking into account the shading effect of measured densities of macroalgae. The term $\left(M_{\mathrm{c}}-M_{\mathrm{s} 1}\right) F$ represents the calculated in situ macroalgal metabolism and this is simply added to the in situ sediment metabolism rate to obtain an estimate of total benthic metabolism. We made this calculation of total benthic metabolism for each replicate field measurement of macroalgal biomass, or bare area if macroalgae were absent (12 to 16 per site). All metabolism measurements are reported in mmol DIC $\mathrm{m}^{-2} \mathrm{~d}^{-1}$.

Statistical analysis. Differences in metabolism between sites were tested using 2-way ANOVA with site and time as main factors. Comparisons among microcosm treatments (light vs dark) and in situ primary producer biomass (by site) were made using 1 -way ANOVA. Differences were accepted as significant at $\mathrm{p}<0.05$. 


\section{RESULTS}

\section{Community production and respiration}

Differences between light and dark microcosm incubations averaged over the 3 seasons (spring, summer, fall) clearly showed significant autotrophic production by the benthic macroalgal and microalgal populations at all sites $(\mathrm{p}<0.002$; Fig. $5 \mathrm{~b}, \mathrm{c})$. Net production rates for the sediment + macroalgae community measured in the light incubations ranged from 23.1 to $30.6 \mathrm{mmol}$ $\mathrm{C} \mathrm{m}^{-2} \mathrm{~h}^{-1}$, and dark respiration rates ranged from 9.9 to $12.4 \mathrm{mmol} \mathrm{C} \mathrm{m}^{-2} \mathrm{~h}^{-1}$ (Fig. 5c). Overall, there were no significant differences in either net production or dark respiration rates between sites $(p=0.23$ and $p=0.73$; Fig. 5c). For the incubations with sediment only, average net production rates in the light were about 5 -fold smaller than when macroalgae were present (3.7 to $6.6 \mathrm{mmol} \mathrm{C} \mathrm{m}^{-2} \mathrm{~h}^{-1}$; Fig. 5b). Respiration rates also were lower, approximately 3 -fold less than in sediment incubations containing macroalgae $(0.9$ to $2.7 \mathrm{mmol} \mathrm{C}$ $\mathrm{m}^{-2} \mathrm{~h}^{-1}$; Fig. 5b). Net production rates and dark respiration rates for the sediment cores were not significantly different between sites ( $p=0.58$ and $p=0.57$ ). For the water column, differences between light and dark incubations were insignificant when averaged over the seasons $(\mathrm{p}=0.79,0.57$ and 0.87 for Creek, Shoal and Hog sites; Fig. 5a). Phytoplankton production was only evident in August at all sites (Fig. 6a) when DIC consumption in the light decreased with distance from the mainland $(27.8 \pm 3.1,15.8 \pm 8.9$ and $12.9 \pm 3.1 \mathrm{mmol} \mathrm{DIC} \mathrm{m}^{-2} \mathrm{~h}^{-1}$ for the Creek, Shoal and Hog sites).

Net primary production rates of macroalgae in the microcosms are shown in Table 2, and are comparable to rates reported in the literature. Analysis of the macroalgal tissue showed that there was a general decrease in \% $\mathrm{N}$ content from the Creek to the Hog site (Table 3), indicating a gradient of high to low $\mathrm{N}$ availability from the mainland seaward. At all sites, the lowest tissue $\mathrm{N}$ content was found in May, when the growth demand for $\mathrm{N}$ relative to the $\mathrm{N}$ supply was probably the highest.

The hourly metabolism rates from the microcosms were scaled to the number of light and dark hours for each sampling period to calculate daily net metabolism rates for each community on a per $\mathrm{m}^{2}$ basis. Seasonal differences in metabolism were evident for all autotrophic components of the system (Fig. 6). The water column was heterotrophic or in balance in the spring and fall and was autotrophic in the summer (Fig. 6a). At all sites, the water column was most heterotrophic in the fall. There were no differences in water column metabolism between sites in any season (site $\times$ time; $p=0.93$ ). Sediments were slightly auto-
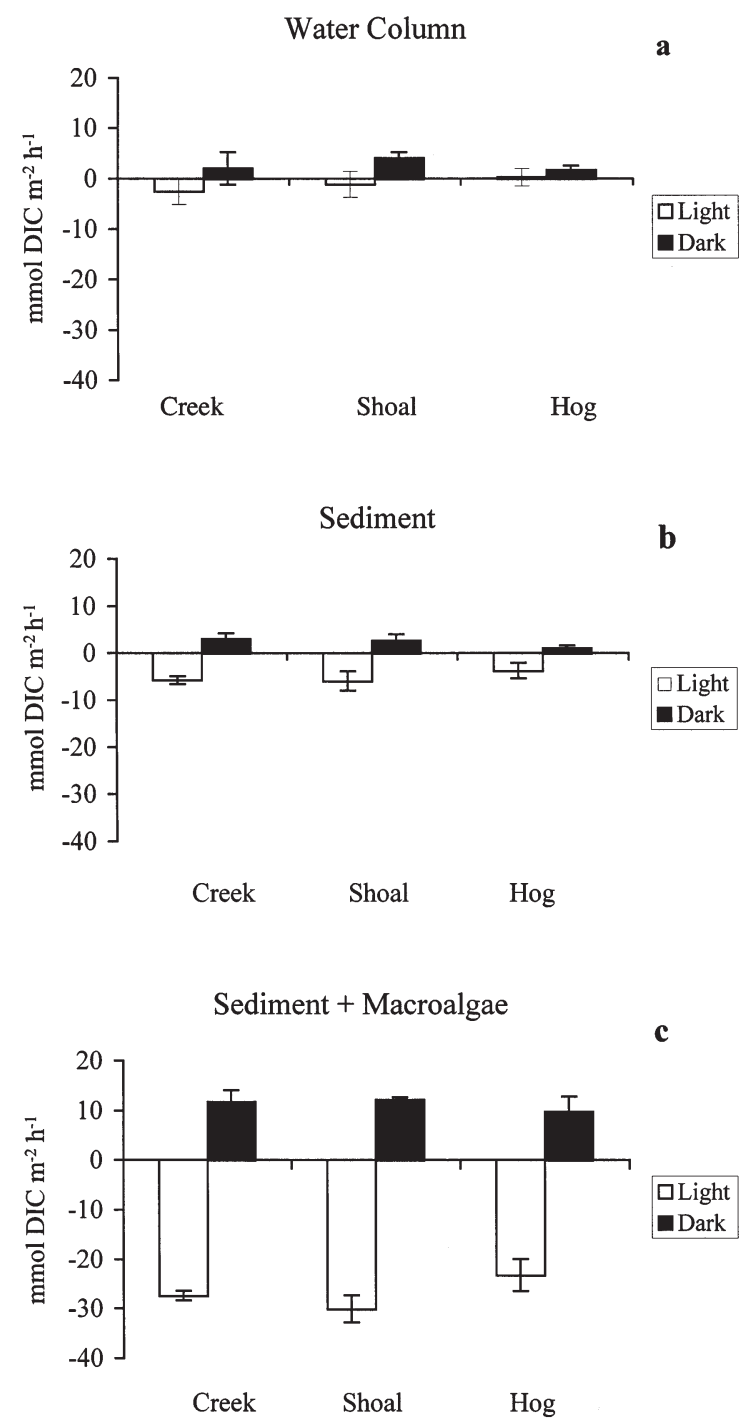

Fig. 5. Seasonal averages of light and dark microcosm incubations for the (a) water column, (b) sediment, and (c) sediment+macroalgae. The benthic metabolism values are corrected for water column activity. The water column metabolism rates are calculated for a depth of $1 \mathrm{~m}$. Values are calculated as the average of the seasonal (spring, summer, fall) means ( $\mathrm{n}=3$ for each season). The error bars (SE) represent variation between the seasons

trophic or in balance in the spring and fall at all sites and were more markedly autotrophic in mid-summer,

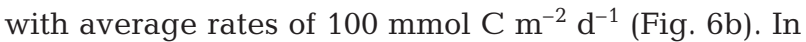
all the seasons sampled, daily net sediment metabolism was similar between the sites (site $\times$ time; $\mathrm{p}=$ $0.15)$. The benthic community in the microcosms containing macroalgae was always strongly autotrophic, with highest rates in mid-summer when temperature and light conditions were conducive to growth, and lowest rates in fall (Fig. 6c). At the biomass densities used in the microcosms, maximum rates of daily net 

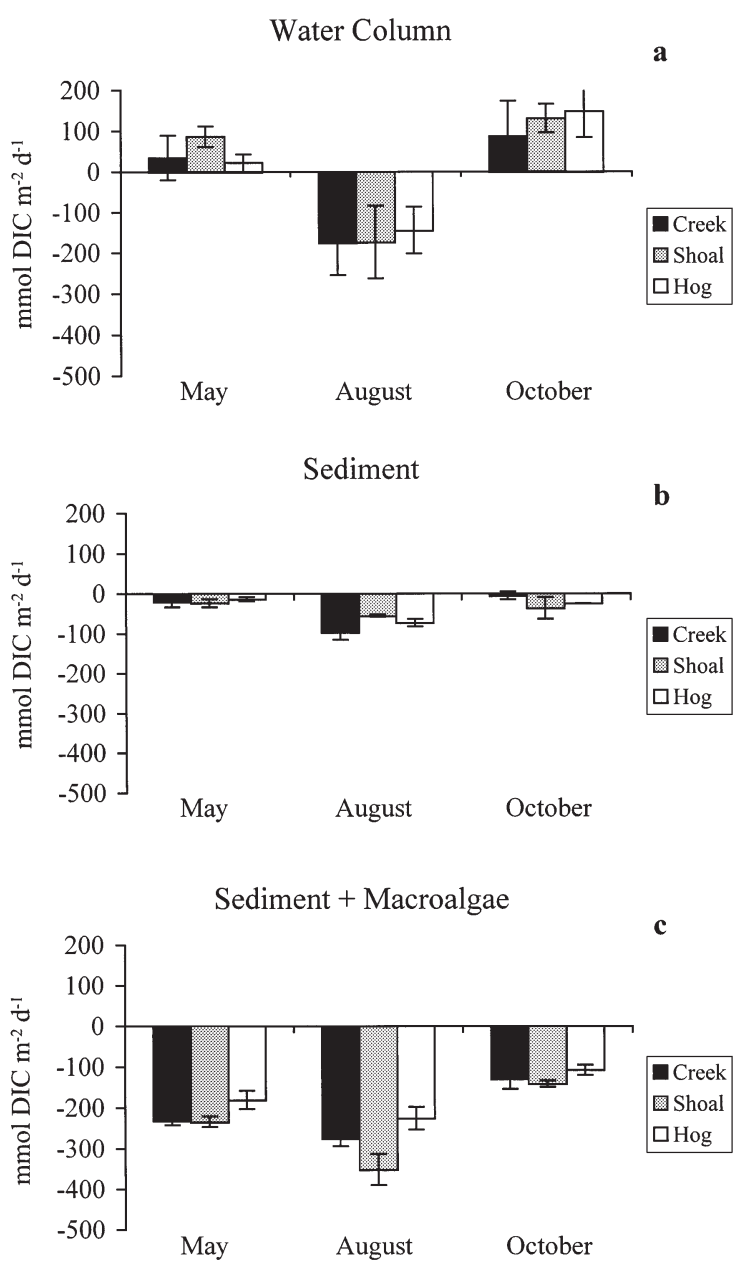

Fig. 6. Daily metabolism rates determined from the microcosms for the (a) water column, (b) sediment, and (c) sediment+macroalgal communities calculated from light and dark incubations and normalized to the number of light and dark hours each month. The water column metabolism rates are calculated for a depth of $1 \mathrm{~m}$. Values represent means $(\mathrm{n}=3)$ $\pm 1 \mathrm{SE}$

production were about 4 to 5 times higher than those for the benthic microalgal community.

\section{Autotroph biomass}

Macroalgal biomass was highly variable throughout the lagoon, with densities ranging from 0 to $650 \mathrm{gdw}$ $\mathrm{m}^{-2}$ during the year. There was a distinct seasonal pattern in biomass, with an early summer peak followed by a decline in biomass by late summer at all sites, and a subsequent accumulation through the fall and winter months until the next summer peak (Fig. 7b). Biomass was always highest at the mid-lagoon Shoal site $(\mathrm{p}<$ $0.003)$, and thick $(30 \mathrm{~cm})$ mats developed in localized areas in early summer. In these areas, the macroalgal collapse led to a temporary period of anoxia throughout the water column and a significant flux of macroalgal-bound nutrients to the water column (Tyler et al. 2001). The macroalgal decline at all sites was followed by increase in water column chl a (Fig. 7a). Water column chl a concentrations were typically lower at the Hog Island embayment site than at the Creek and Shoal sites $(p=0.06)$. In July, water column chl a concentrations reached a high of $12 \mu \mathrm{g} \mathrm{l}^{-1}$ at the Creek and Shoal sites, and a lower peak of $\sim 5 \mu \mathrm{g} \mathrm{l}^{-1}$ at the Hog Island site furthest offshore. In October, concentrations
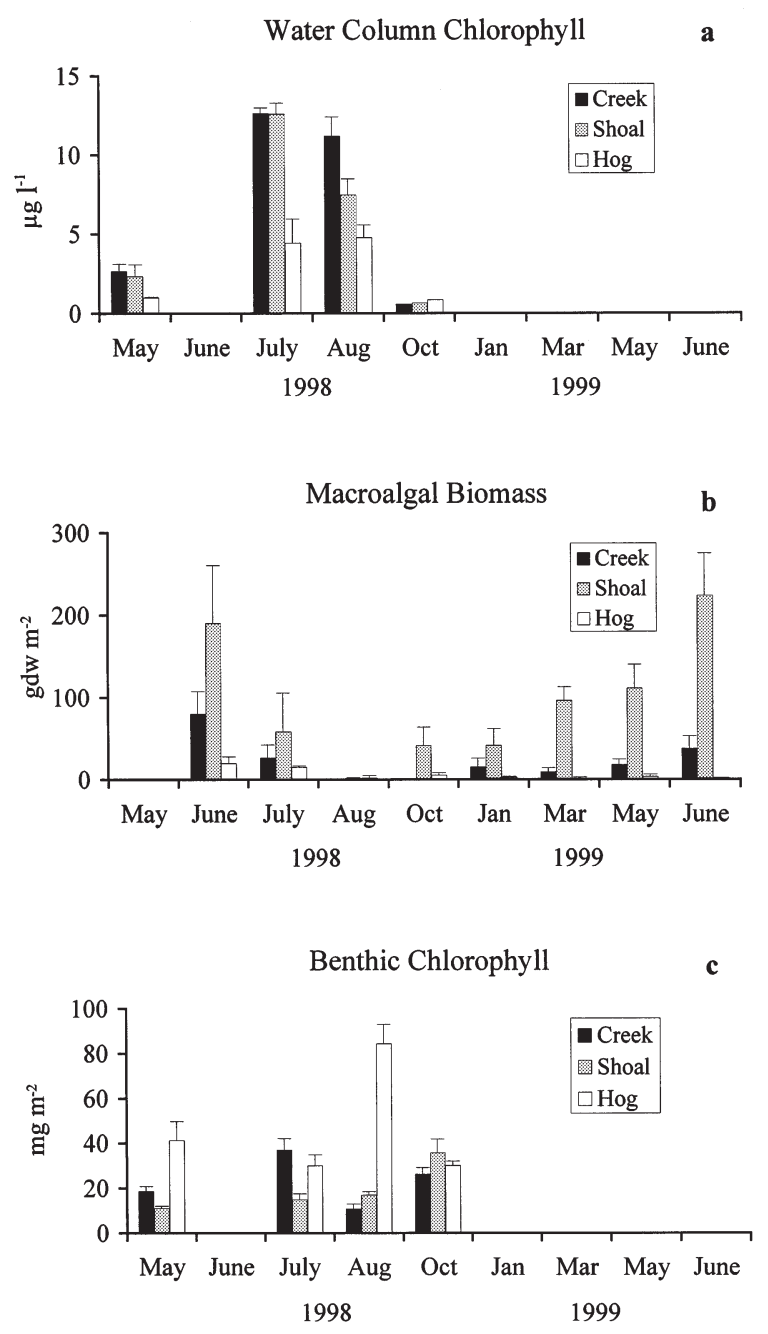

Fig. 7. Distribution of primary producer biomass at the 3 sites in Hog Island Bay. Water column (a) and sediment (b) chlorophyll values were determined from samples used for the metabolism incubations. Benthic macroalgal distribution (c) was determined at 2 locations for each site (6 to 8 replicate measurements at each location) throughout the year. Values are means ( $\mathrm{n}=3$ for water column and sediment chlorophyll, and $\mathrm{n}=12$ to 16 for macroalgal biomass). Error bars represent 
Table 2. Comparison of macroalgal production rates (chlorophytes)

\begin{tabular}{|c|c|c|c|}
\hline Site & Species & $\begin{array}{c}\text { Production } \\
\left(\mathrm{mmol} \mathrm{C} \mathrm{gdw}^{-1} \mathrm{~h}^{-1}\right)\end{array}$ & Source \\
\hline Hog Island Bay, Virginia, USA & Ulva lactuca & $0.1-0.26^{\mathrm{a}}$ & This study \\
\hline Roskilde Fjord, Denmark & Chaetomorpha linum & $1-1.1^{\mathrm{b}}$ & McGlathery \& Pedersen (1999) \\
\hline Kertinge Nor, Denmark & Chaetomorpha linum & $0.06^{\mathrm{c}}$ & Krause-Jensen et al. (1996) \\
\hline Waquoit Bay, Massachusetts, USA & Cladophora vagabunda & $0.25-0.67^{\mathrm{d}}$ & Peckol \& Rivers (1996) \\
\hline Harrington Sound, Bermuda & Cladophora prolifera & $0.04^{\mathrm{e}}$ & Lapointe \& O'Connell (1989) \\
\hline Beaufort, North Carolina, USA & Ulva rotunda & $1.5-2^{\mathrm{f}}$ & Henley \& Ramus (1989) \\
\hline \multicolumn{4}{|c|}{$\begin{array}{l}\text { a Microcosm incubations in outdoor flowing seawater table } \\
\text { b Laboratory incubation in growth chamber } \\
{ }^{\mathrm{c}} \text { Laboratory flow-through experiment in growth chamber } \\
{ }^{\mathrm{d}} \text { Field incubation } \\
{ }^{\text {e}} \text { Outdoor flowing seawater system, } \mathrm{O}_{2} \text { production values converted to } \mathrm{C} \text { fixed using photosynthetic quotient of } 1 \\
{ }^{\mathrm{f}} \text { Incubation in outdoor flowing seawater table, } \mathrm{O}_{2} \text { production values converted to C fixed using photosynthetic quotient of } 1\end{array}$} \\
\hline
\end{tabular}

Table 3. Macroalgal tissue carbon and nitrogen content $(x \pm \mathrm{SE})$. Values represent \% of algal dry weight

\begin{tabular}{|lccc|}
\hline Site & $\% \mathrm{C}$ & $\% \mathrm{~N}$ & $\mathrm{C}: \mathrm{N}$ (molar) \\
\hline Creek & & & \\
May & $32.0 \pm 0.78$ & $1.8 \pm 0.14$ & $20.3 \pm 1.09$ \\
August & $33.1 \pm 0.39$ & $2.2 \pm 0.15$ & $17.8 \pm 1.11$ \\
October & $31.6 \pm 0.43$ & $3.6 \pm 0.06$ & $10.1 \pm 0.16$ \\
Shoal & & & \\
May & $24.6 \pm 2.14$ & $1.5 \pm 0.13$ & $19.6 \pm 0.21$ \\
August & $32.6 \pm 0.37$ & $2.2 \pm 0.17$ & $17.7 \pm 1.29$ \\
October & $30.6 \pm 2.10$ & $2.7 \pm 0.19$ & $13.3 \pm 0.52$ \\
Hog & & & \\
May & $30.6 \pm 1.50$ & $0.80 \pm 0.05$ & $44.7 \pm 1.48$ \\
August & $30.5 \pm 1.6$ & $1.1 \pm 0.15$ & $33.6 \pm 3.28$ \\
October & $27.9 \pm 1.47$ & $1.8 \pm 0.15$ & $18.4 \pm 2.23$ \\
\hline
\end{tabular}

were $<1 \mu \mathrm{g} \mathrm{l^{-1 }}$ at all sites (Fig. 7a) and remained at low levels during much of the winter (K.J.M. et al. unpubl. data). Sediment chl a was variable at all sites and showed no clear trend in concentration between months (Fig. 7c). Despite the usefulness of chl a concentrations as an index of photosynthetic potential of benthic microalgal populations, we found no strong relationship between chl a concentrations and either net production in the light incubations or daily net production in individual cores $\left(\mathrm{R}^{2}=0.019\right.$ and 0.043, respectively; $\mathrm{p}>0.05$ ).

\section{Benthic versus pelagic community metabolism}

Daily in situ benthic community metabolism calculated from the core incubations and extrapolated to field densities of macroalgae and the proportion of bare sediment colonized by microalgae showed that the benthic community at all 3 sites in the lagoon was net autotrophic (Fig. 8). Rates of DIC consumption ranged from a low of $6 \mathrm{mmol} \mathrm{C} \mathrm{m} \mathrm{C}^{-2}$ at the mainland Creek site in the fall to a high of $179 \mathrm{mmol} \mathrm{C} \mathrm{m}^{-2} \mathrm{~d}^{-1}$ at the mid-lagoon Shoal site in late spring. There were significant differences between the sites during all 3 seasons sampled (site $\times$ time; $p<0.0001$ ). Rates of DIC consumption were generally highest at the Shoal site, except in the late summer following the macroalgal collapse, when net autotrophic metabolism was highest for the benthic community at the Creek site. At the Shoal site, the benthic community was most strongly net autotrophic in May as macroalgal biomass accumulated in dense mats. Net autotrophy of the benthic community declined following the macroalgal crash, and then increased again in the fall as macroalgae returned to the site (Fig. 8, Table 4). About $85 \%$ of the benthic production in late summer following the macroalgal collapse could be attributed to sediment microalgal metabolism (Table 4). At the mainland Creek site, daily DIC consumption in the spring was lower than the Shoal site, largely due to the lower macroalgal biomass. Benthic microalgae contributed the most to benthic autotrophy at this nearshore site in the late summer and fall (Table 4). Rates of benthic metabolism were relatively low at the Hog site, and net autotrophy could be attributed largely to the activity of the sediment microalgae during all 3 seasons sampled (Table 4). It was only in August, when the macroalgae had declined at the 2 sites closest to the mainland, that benthic production at the embayment site was relatively high.

For comparison with the benthic community, we scaled the daily DIC fluxes from the water column microcosms to a $\mathrm{m}^{2}$ basis using an average water column height of $1 \mathrm{~m}$ for the 3 sites. There were no significant differences in water column metabolism between 


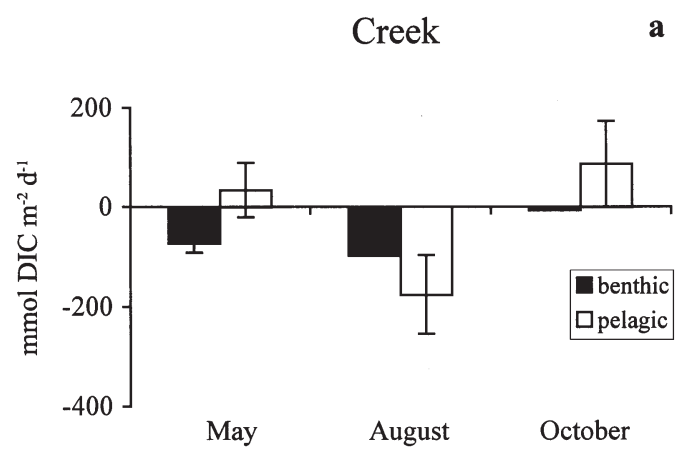

Shoal

b

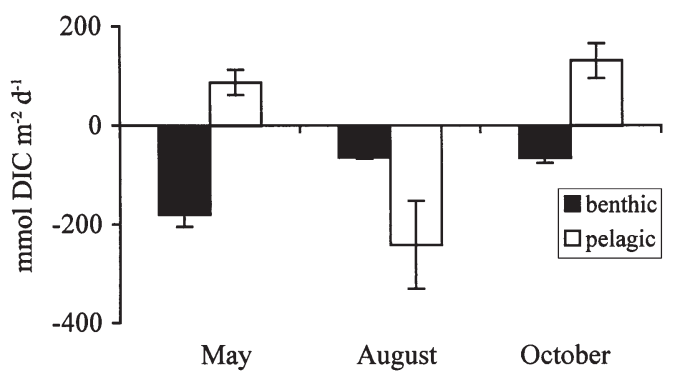

Hog

c

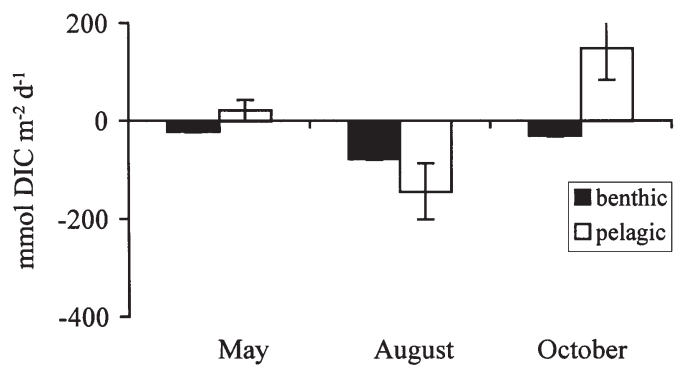

Fig. 8. Benthic vs pelagic metabolism at each site during the spring, summer and fall $(x \pm S E, n=3)$. Benthic metabolism was calculated based on the DIC exchange rates determined from the microcosm incubations, in situ measurements of macroalgal biomass and bare area colonized by benthic microalgae only. In scaling from the microcosm to in situ rates, benthic metabolism was corrected for both self-shading within the macroalgal mat and shading of the benthic microalgae by macroalgae overlying the sediment surface. Water columnmetabolism was based on a water column height of $1 \mathrm{~m}$

the sites during the sampling periods (site $\times$ time; $\mathrm{p}=$ 0.79). The water column at all 3 sites was net heterotrophic in the spring and even more so in the fall (Fig. 8). It was only following the collapse of the macroalgae in late summer that the water column at all 3 sites was net autotrophic.
Table 4. Percentage of benthic production accounted for by macroalgae and sediment microalgae

\begin{tabular}{|llcc|}
\hline Month & Site & $\begin{array}{c}\text { Microalgae } \\
\text { (\% of benthic production) }\end{array}$ & $\begin{array}{c}\text { Macroalgae } \\
\text { May }\end{array}$ \\
& Creek & 14 & 86 \\
& Shoal & 4 & 96 \\
August & Hog & 62 & 38 \\
& Creek & 98 & 2 \\
& Shoal & 85 & 15 \\
October & Hog & 99 & 1 \\
& Creek & 72 & 28 \\
& Shoal & 32 & 68 \\
& Hog & 81 & 19 \\
\hline
\end{tabular}

\section{DISCUSSION}

\section{Benthic versus pelagic metabolism}

In shallow coastal estuaries and lagoons, where much of the sediment surface is within the euphotic zone, benthic photoautotrophy is recognized as playing an important role in nutrient, oxygen and DIC exchanges across the sediment-water interface (e.g., Rizzo et al. 1996, Viaroli et al. 1996, McGlathery et al. 1997, Valiela et al. 1997, Sundbäck et al. 2000). In Hog Island Bay, about $50 \%$ of the sediment area is $<1 \mathrm{~m}$ depth at MLW, with these shoal areas supporting highly productive benthic microalgal and macroalgal communities. The microcosm incubations described here, coupled with data on in situ macroalgal biomass, and sediment and water column chlorophyll, clearly indicate a seasonality in the dominance of primary producers at the sites, with benthic primary producers being the most important early and late in the growing season and phytoplankton dominating following a mid-summer period of macroalgal decay and release of algal-bound nutrients into the water column. Strong water column heterotrophy in the fall indicated that this peak in phytoplankton production was short-lived.

There were clear differences in benthic metabolism among the 3 sites studied, which reflected a gradient in nutrient availability. Since production of macroalgal communities is known to be stimulated by nutrient inputs (Nilsson et al. 1991, Valiela et al. 1997), and the light attenuation values indicated sufficient light availability to support algal photosynthesis at all sites (Table 1), we might expect the highest rates of benthic production to occur at the nearshore Creek site. However, we found that the mid-lagoon Shoal site generally had the highest rates of benthic production, with these differences being related to variation in macroalgal densities between the sites. Macroalgae accumu- 
lated to the greatest extent at the Shoal site, probably due to physical transport of drifting macroalgae and entrapment by exposed oyster bars in the shoal areas. This is a physically dynamic system, where each year over 30 extratropical storms occur with magnitudes sufficient to elevate tides above astronomical norms (Hayden et al. 1999), generating waves and storm surges. At the more protected barrier island embayment site, the macroalgae were more limited by $\mathrm{N}$ availability, production rates were relatively low, and biomass also remained low throughout the year. Sediment microalgae accounted for the majority of benthic production (62 to $99 \%$ ) at this site during the spring through fall. Despite high nutrient levels at the nearshore Creek site, macroalgal populations also accumulated to a lesser extent than in the mid-lagoon. This may be partly due to episodes of high light attenuation from resuspension of the fine silty sediments during windy periods.

A mid-summer decrease in macroalgal biomass occurred throughout the lagoon, even where populations were sparse, which suggests that light limitation within dense macroalgal mats was not the only mechanism contributing to the decline. It is likely that increased respiratory demands from high summer temperatures resulted in net decomposition. Other possible mechanisms could be increased grazing pressure (Geertz-Hansen et al. 1993, Giannotti \& McGlathery 2001) or advection of macroalgae onto the marshes and mudflats or out to the coastal ocean.

Regardless of the specific mechanism responsible for the macroalgal decline observed, it is clear that it was associated with an increase in water column chlorophyll and phytoplankton production. Our results are consistent with other studies showing dominance of macroalgae over phytoplankton in shallow coastal lagoons and bays, punctuated by periodic shifts to phytoplankton dominance (Sfriso et al. 1992, Valiela et al. 1992, Riisgaard et al. 1995). Such low phytoplankton production has been attributed to nutrient competition between macroalgae and phytoplankton (Fong et al. 1993, Thybo-Christesen \& Blackburn 1993, McGlathery et al. 1997) and to water residence times shorter than phytoplankton duplication times (Valiela et al. 1997). At low-to-moderate nutrient loading rates, macroalgae can sustain maximum growth rates for longer periods of time than phytoplankton because their nutrient storage capacity offsets the need for a constant nutrient supply (Fong et al. 1993, Pedersen \& Borum 1996). Stored nutrients in phytoplankton can only sustain maximum growth for a day or less, whereas growth by ephemeral macroalgae such as Ulva, Cladophora and Chaetomorpha can be sustained by stored nutrients for at least $5 \mathrm{~d}$ (Borum 1996). Macroalgae also can uncouple sediment remineraliza- tion from water column activity by intercepting nutrient fluxes across the sediment-water interface and thereby reducing the amount of nutrients available for phytoplankton production (Thybo-Christesen \& Blackburn 1993, McGlathery et al. 1997). Similarly, the benthic microalgal community may function as a 'filter' to control the flux of dissolved nutrients from the sediment to the overlying water column (RisgaardPetersen et al. 1994, Reay et al. 1995, Sunbäck et al. 2000). In Hog Island Bay, the sediments were not a significant source of inorganic nitrogen to the water column during the seasons studied despite high mineralization rates (Anderson et al. unpubl.). This suggests that bacterial and/or benthic microalgal assimilation and/or denitrification rates were high. Although sediments are generally considered to be a significant internal source of nutrients in shallow coastal systems, several studies have shown that sandy sediments which support productive microalgal communities may be net sinks of dissolved nutrients during certain times of the year (Nilsson et al. 1991, Rizzo et al. 1992, Sunbäck et al. 2000). It is likely that benthic primary producers in Hog Island Bay relied, at least in part, on water column $\mathrm{N}$ to meet their growth demands and that there was competition with phytoplankton for water column nutrients during the spring and early summer when growth rates were high. Following the release of both DIN and DON to the water column from senescing macroalgae, phytoplankton production would be stimulated either by direct uptake or by indirect assimilation following bacterial mineralization of DON in the water column.

Benthic microalgal production also increased in importance following the macroalgal decline at all 3 sites, suggesting that competition for light limited benthic microalgal production occurred when macroalgal densities were high. Surprisingly, there have been few direct studies of resource competition between matforming macroalgae and benthic microalgae (Sundbäck et al. 1990, 1996). Persistent, dense macroalgal mats would be expected to affect production of sediment microalgal communities by reducing light levels and by creating anoxic conditions at the sediment surface. At lower densities, or when macroalgae are floating in the water column and do not create intense shading and/or bottom water anoxia, sediment microalgal production would not be as strongly influenced (Sundbäck et al. 1996).

\section{Patterns of autotrophy and heterotrophy}

It is difficult to scale hourly metabolism rates obtained from enclosed microcosm incubations of the sediment or water column to total metabolism, because 
sampling may not be representative and/or because 'bottle effects' might lead to resource limitation during the incubations (Kemp \& Boynton 1980). On the other hand, in situ 'open water' techniques to estimate total system metabolism may be difficult to apply in hydrologically complex lagoonal ecosystems where water residence times can vary significantly in different parts of the lagoon (Oliveira \& Baptista 1997). We do not have concurrent total metabolism measurements using the 'open water' method at our 3 sites for comparison. However, since the water column in our study is shallow and well-mixed, we would expect to find a reasonable correspondence between the microcosm incubations and 'open-water' measurements (Kemp \& Boynton 1980). In addition, changes in DIC and DIN concentrations during our water column incubations did not show signs of $\mathrm{C}$ or $\mathrm{N}$ limitation that would have led to underestimation of metabolism. Our estimates of total daily metabolism at our sites fall within the range of those reported for other coastal lagoons (Table 5). Nonetheless, we restrict our discussion to the general patterns of trophic status at the 3 sites studied.

There was a distinct seasonality in patterns of system autotrophy and heterotrophy at all sites within Hog Island Bay, where all sites were net autotrophic in the spring and summer and net heterotrophic in the fall. This is in general agreement with other recent studies in shallow coastal lagoons that have shown a shift from net autotrophy during spring and summer months to net heterotrophy in winter regardless of whether the systems were phytoplankton or macrophyte dominated (Carmouze et al. 1991, 1998, Reyes \& Merino 1991). These patterns can be driven by either biological or physical processes. Carmouze et al. (1998) suggested that the seasonal switch from autotrophy to heterotrophy in several subtropical lagoons in Brazil was driven by low phytoplankton activity in the winter as temperature and irradiance levels became less conducive to growth. Conversely, Reyes \& Merino (1991) attributed strong winter heterotrophy in a macrophytedominated tropical lagoon to resuspension and rapid degradation of organic-rich sediments during winter storms. In Hog Island Bay, the pattern of autotrophy and heterotrophy at the 3 sites appeared to be linked, at least in part, to macroalgal metabolism, either directly, when macroalgal biomass was high in the spring and early summer, or indirectly as nutrients released from the decomposition of macroalgae temporarily stimulated phytoplankton production and bacterial metabolism in the water column. Whatever the specific mechanism, it appears that a seasonal shift between net autotrophy and heterotrophy may be a common feature of coastal lagoons (Knoppers et al. 1991). Such a shift also has been found in a mesocosm experiment, where there was a seasonal pattern of autotrophy during the winter-spring diatom bloom and

Table 5. Comparison of daily metabolism measurements in coastal lagoons. Reported values integrate sediment and overlying water column

\begin{tabular}{|c|c|c|c|c|}
\hline Location & Season & $\begin{array}{c}\text { Metabolism } \\
\left(\mathrm{mmol} \mathrm{C} \mathrm{m}^{-2} \mathrm{~d}^{-1}\right)\end{array}$ & $\begin{array}{c}\text { Dominant } \\
\text { plant community }\end{array}$ & Source \\
\hline \multirow[t]{3}{*}{$\begin{array}{l}\text { Hog Island Bay, } \\
\text { Virginia, USA }\end{array}$} & Spring & -92 to $1^{a}$ & $\begin{array}{l}\text { Macroalgae/ } \\
\text { benthic microalgae }\end{array}$ & This study \\
\hline & Summer & -305 to $-221^{a}$ & $\begin{array}{l}\text { Macroalgae/ } \\
\text { phytoplankton }\end{array}$ & This study \\
\hline & Fall & 65 to $118^{a}$ & $\begin{array}{l}\text { Macroalgae/ } \\
\text { benthic microalgae }\end{array}$ & This study \\
\hline \multirow{2}{*}{$\begin{array}{l}\text { Barro Lagoon, } \\
\text { Brazil }\end{array}$} & Summer & $-11^{\mathrm{b}}$ & Phytoplankton & Carmouze et al. (1998) \\
\hline & Winter & $37^{b}$ & Phytoplankton & Carmouze et al. (1998) \\
\hline \multirow{4}{*}{$\begin{array}{l}\text { Newport River Estuary, } \\
\text { North Carolina, USA }\end{array}$} & Winter & 12 to $31^{\mathrm{c}}$ & Phytoplankton & Kenney et al. (1998) \\
\hline & Spring & $-17^{\mathrm{c}}$ & Phytoplankton & Kenney et al. (1998) \\
\hline & Summer & $-24^{\mathrm{c}}$ & Phytoplankton & Kenney et al. (1998) \\
\hline & Fall & $-17^{\mathrm{c}}$ & Phytoplankton & Kenney et al. (1998) \\
\hline \multirow[t]{2}{*}{$\begin{array}{l}\text { Borjorquez Lagoon, } \\
\text { Yucatan, Mexico }\end{array}$} & $\begin{array}{l}\text { Range } \\
\text { during }\end{array}$ & -306 to $213^{d}$ & $\begin{array}{l}\text { Seagrass/ } \\
\text { macroalgae }\end{array}$ & Reyes \& Merino (1991) \\
\hline & year & -188 to $128^{d}$ & $\begin{array}{l}\text { Phytoplankton/ } \\
\text { macroalgae }\end{array}$ & Reyes \& Merino (1991) \\
\hline \multicolumn{5}{|c|}{$\begin{array}{l}{ }^{\text {a }} \text { Diel changes in DIC in microcosm incubations in outdoor flowing seawater table at } 3 \text { stations } \\
\text { bDiel changes in } \mathrm{CO}_{2} \text { in entire water column (free water and in plexiglass tubes with and without sediments) at } 1 \text { location } \\
{ }^{c} \text { Diel changes in } \mathrm{O}_{2} \text { measured in water column at mid-depth at } 1 \text { station on samples taken with a horizontal van Dorn bottle } \\
\text { d Diel changes in } \mathrm{O}_{2} \text { measured at } 2 \text { depths in water column at } 4 \text { stations }\end{array}$} \\
\hline
\end{tabular}


heterotrophy during summer and early fall when the diatoms were likely nutrient (silica) limited (Oviatt et al. 1986). The strong fall heterotrophy in Hog Island Bay reflects both low benthic autotrophy and high pelagic heterotrophy, the latter probably due to nutrient limitation of phytoplankton coupled with high bacterial metabolism. Low temperatures in the fall also may have decreased autotrophic metabolism of both benthic and pelagic communities. Kemp et al. (1997) also described a period of net heterotrophy in the fall in the lower Chesapeake Bay and attributed this to nutrient limitation and the seasonal input of seagrass detritus.

\section{Implications for fate and retention of $\mathrm{N}$ in $\mathrm{Hog}$ Island Bay}

Assimilation by macroalgae and other autotrophs in Hog Island Bay represents a temporary retention of nutrients within the system unless significant burial or export of particulate organic matter occurs. The degree to which retention of nutrients in plant biomass slows nutrient transport to the coastal ocean will depend largely on the tissue nutrient content and turnover time of the primary producers. Nutrient turnover rates are highest for phytoplankton and benthic macroalgae (low C:N content and rapid growth rates), moderate for ephemeral macroalgae, and lowest for perennial macroalgae and seagrasses (high C:N and slower growth rates) (Buchsbaum et al. 1991, Enriquez et al. 1993). The dominance of fast-growing ephemeral macroalgae and phytoplankton over seagrasses in enriched lagoons can feed back to accelerate nutrient cycling rates such that nutrient retention time is decreased. Nutrients that are released upon senescence can be reassimilated by other autotrophs or bacteria, exported as dissolved inorganic or organic forms, or denitrified.

In order to relate $\mathrm{C}$ metabolism to $\mathrm{N}$ assimilation by the different primary producer communities within Hog Island Bay, we calculated the $\mathrm{N}$ required to support autotrophic production based on our measurements of carbon metabolism and tissue C:N. We used our measured values for macroalgal C:N, the Redfield $\mathrm{C}: \mathrm{N}$ ratio of 6.6 for the water column, and a C:N ratio of 9, reported by Sundbäck et al. (2000) for the benthic microalgal communities in similar shallow-water sediments. In the spring, macroalgae were the strongest sink for $\mathrm{N}$ at the 2 sites closest to shore, with $\mathrm{N}$ assimilation rates ranging from 3.1 to $9.5 \mathrm{mmol} \mathrm{N} \mathrm{m}^{-2}$ $\mathrm{d}^{-1}$. Nutrients accumulated in macroalgal biomass throughout the spring and early summer; we calculated the total $\mathrm{N}$ pool accumulated by algae prior to their decline to be $129 \mathrm{mmol} \mathrm{N} \mathrm{m}^{-2}$ at the nearshore
Creek site and $571 \mathrm{mmol} \mathrm{N} \mathrm{m}^{-2}$ at the mid-lagoon Shoal site. This large capacity for nutrient retention in macroalgal tissue clearly was only temporary. Tyler et al. (2001) measured flux rates of dissolved organic and inorganic $\mathrm{N}$ and calculated that at the mid-lagoon Shoal site, where dense macroalgal populations collapsed, it would take $<2$ wk for the macroalgal material to be completely remineralized. It was only immediately following the macroalgal decline at all sites throughout the lagoon that the water column and benthic microalgal communities became a strong sink for $\mathrm{N}$. Assimilation rates were high $(6.0$ to $10.6 \mathrm{mmol} \mathrm{N}$ $\mathrm{m}^{-2} \mathrm{~d}^{-1}$ for the benthic microalgal community and 21.8 to $26.4 \mathrm{mmol} \mathrm{N} \mathrm{m}^{-2} \mathrm{~d}^{-1}$ for the water column), but since turnover rates also were high and the peak in production was short-lived, nutrient retention by these communities was shorter than for the macroalgae. Seagrasses have recently returned as isolated patches in some lagoons of the Virginia Coast Reserve. If this trend continues and seagrasses recolonize Hog Island Bay and replace benthic algae as the dominant primary producers, we would expect an increase in the retention of nutrients in slowly degradable seagrass tissue. Clearly, the character and composition of the autotrophic community plays a key role in determining the extent to which these shallow coastal estuaries and lagoons function as a filter to temporarily retain or permanently remove nutrients in their trajectory from the land to the coastal ocean.

Acknowledgements. We thank the many graduate and undergraduate students who provided field and laboratory assistance: Eva Bailey, Katie Bolcar, Ishi Buffam, Jessica Burton, Tracie Mastronicola, Alan Moore, Jennifer Rosinski, Krissy Russell, Liz Skane and Mads Thomsen. Betty Neikirk provided valuable technical assistance and Peter Berg helped with the model calculations. Finally, we thank the staff of the University of Virginia LTER field station and the Virginia Institute of Marine Science Wachapreague field station for their logistical support. This work was supported by the Virginia Coast Reserve LTER Project (NSF \#DEB-9411974) and by NSF grant \#DEB-9805928 to K.J.M.

\section{LITERATURE CITED}

Anderson IC, Tobias CR, Neikirk BB, Wetzel RL (1997) Development of a process-based nitrogen mass balance model for a Virginia (USA) Spartina aterniflora salt marsh: implications for net DIN flux. Mar Ecol Prog Ser 159:13-27

Blackburn TH, Henriksen K (1983) Nitrogen cycling in different types of sediments from Danish waters. Limnol Oceanogr 28:477-493

Bohlke JK, Denver JM (1995) Combined use of groundwater dating, chemical, and isotopic analyses to resolve the history and fate of nitrate contamination in two agricultural watersheds, Atlantic coastal plain, Maryland. Water Resour Res 31:2319-2339

Borum J (1996) Shallow waters and land/sea boundaries. In: Jørgensen BB, Richardson K (eds) Eutrophication in coastal marine ecosystems. Coastal and Estuarine Studies, 
Vol 52. American Geophysical Union, Washington, DC, p 179-203

Borum J, Sand-Jensen K (1996) Is total primary production in shallow coastal marine waters stimulated by nitrogen loading? Oikos 76:406-410

Boynton WR, Hagy JD, Murray L, Stokes C, Kemp WM (1996) A comparative analysis of eutrophication patterns in a temperate coastal lagoon. Estuaries 19:408-421

Buchsbaum R, Valiela I, Swain T, Dzierzeski M, Allen S (1991) Available and refractory nitrogen in detritus of coastal vascular plants and macroalgae. Mar Ecol Prog Ser 72: 131-143

Carmouze JP, Knoppers B, Vasconcelos P (1991) Metabolism of a subtropical Brazilian lagoon. Biogeochemistry 14: $129-148$

Carmouze JP, de Farias B, Bernardes MC, Kuroshima KN (1998) Benthic influence on the metabolism of a shallow tropical lagoon (Lagoa de Barra, Brazil). Hyrobiologia 373/374:89-100

D'Avanzo C, Kremer JN, Wainright SC (1996) Ecosystem production and respiration in response to eutrophication in shallow temperate estuaries. Mar Ecol Prog Ser 141: 263-274

Enriquez S, Duarte CM, Sand-Jensen K (1993) Patterns in decomposition rates among photosynthetic organisms: the importance of detritus C:N:P content. Oecologia 94: $457-471$

Flores-Verdugo FJ, Day JW Jr, Mee L, Briseno-Duenes R (1998) Phytoplankton production and seasonal biomass variation of seagrasses, Ruppia maritima L., in a tropical Mexican lagoon with an ephemeral inlet. Estuaries 11: $51-56$

Fong P, Donohoe RM, Zedler JB (1993) Competition with macroalgae and benthic cyanobacterial mats limits phytoplankton abundance in experimental microcosms. Mar Ecol Prog Ser 100:97-102

Geertz-Hansen O, Sand-Jensen K, Hansen DF, Christiansen A (1993) Growth and grazing control of abundance of the marine macroalga, Ulva lactuca (L.) in a eutrophic Danish estuary. Aquat Bot 46:101-109

Giannotti AL, McGlathery KJ (2001) Consumption of Ulva lactuca (Chlorophyta) by the omnivorous mud snail (Ilyanassa obsoleta). J Phycol 37:1-7

Hamilton PA, Helsel DR (1995) Effects of agriculture on ground-water quality in five regions of the United States. Ground Water 33:217-226

Hayden BP (1999) Climate change and extratropical storminess in the United States: an assessment. J Am Water Res Assoc 35:1387-1397

Henley WJ, Ramus J (1989) Photoacclimation of Ulva rotundata (Chlorophyta) under natural irradiance. Mar Biol 103: 261-266

Kemp WM, Boynton WR (1980) Influence of biological and physical processes on dissolved oxygen dynamics in an estuarine system: implications for measurement of community metabolism. Estuar Coast Mar Sci 11:407-431

Kemp WM, Smith EM, Marvin-DiPasquale M, Boynton WR (1997) Organic carbon balance and net ecosystem metabolism in Chesapeake Bay. Mar Ecol Prog Ser 150:229-248

Kenney BE, Litaker W, Duke CS, Ramus J (1988) Community oxygen metabolism in a shallow tidal estuary. Estuar Coast Shelf Sci 27:33-43

Knoppers B, Kjerfve B, Carmouze JP (1991) Trophic state and water turn-over time in six choked coastal lagoons in Brazil. Biogeochemistry 14:149-166

Krause-Jensen D, McGlathery KJ, Rysgaard S, Christensen PB (1996) Production within dense mats of the filamentous macroalga Chaetomorpha linum in relation to light and nutrient availability. Mar Ecol Prog Ser 134:207-216

Lapointe BE, O'Connell J (1989) Nutrient-enhanced growth of Cladophora prolifera in Harrington Sound, Bermuda: eutrophication of a confined, phosphorus-limited marine ecosystem. Estuar Coast Shelf Sci 28:347-360

Lorenzen C (1967) Determination of chlorophyll and phaeopigments: spectrophotometric equations. Limnol Oceanogr 12:343-346

McComb AJ, Humphries R (1992) Loss of nutrients from catchments and their ecological impacts in the PeelHarvey estuarine system, Western Australia. Estuaries 15: 529-537

McGlathery KJ, Pedersen MF (1999) Effect of growth irradiance on the coupling of carbon and nitrogen metabolism in Chaetomorpha linum (Chlorophyta). J Phycol 35:721-731

McGlathery KJ, Krause-Jensen D, Rysgaard S, Christensen PB (1997) Patterns of ammonium uptake within dense mats of the filamentous macroalgae Chaetomorpha linum. Aquat Bot 59:99-115

McIntyre HL, Geider RL, Miller DC (1996) Microphytobenthos: the ecological role of the 'secret garden' of unvegetated, shallow-water marine habitats. I. Distribution, abundance and primary production. Estuaries 19:186-201

Nilsson P, Jönsson B, Lindström Swanberg I, Sundbäck K (1991) Response of a marine shallow-water sediment system to an increased load of inorganic nutrients. Mar Ecol Prog Ser 71:275-290

Nixon SW (1982) Nutrient dynamics, primary production and fisheries yields of lagoons. Oceanol Acta 357-371

Nowicki BL, Nixon SW (1985) Benthic community metabolism in a coastal lagoon ecosystem. Mar Ecol Prog Ser 22:21-30

Oliveira A, Baptista AM (1997) Diagnostic modeling of residence times in estuaries. Water Resour Res 33:1935-1946

Oviatt CA, Keller AA, Sampou PA, Beatty LL (1986) Patterns of productivity during eutrophication: a mesocosm experiment. Mar Ecol Prog Ser 28:69-80

Paerl HW, Rudek J, Mallin MA (1990) Stimulation of phytoplankton production in coastal waters by natural rainfall inputs: nutritional and trophic implication. Mar Biol 107: $247-254$

Peckol P, Rivers JS (1996) Contribution by macroalgal mats to primary production of a shallow embayment under high and low nitrogen-loading rates. Estuar Coast Shelf Sci 43: 311-325

Pedersen MF, Borum J (1996) Nutrient control of algal growth in estuarine waters. Nutrient limitation and the importance of nitrogen requirements and nitrogen storage among phytoplankton and species of macroalgae. Mar Ecol Prog Ser 142:261-272

Pinckney JL, Zingmark RG (1994) Comparison of high-performance liquid chromatographic, spectrophotometric, and fluorometric methods for determining chlorophyll a concentrations in estuarine sediments. J Microbiol Methods 19:59-66

Reay WG, Gallager DL Simmons GM Jr (1992) Groundwater discharge and its impact on surface water quality in a Chesapeake Bay inlet. Water Res Bull 28:1121-1133

Reay WG, Gallagher DL, Simmons GM Jr (1995) Sedimentwater column oxygen and nutrient fluxes in nearshore environments of the lower Delmarva Peninsula, USA. Mar Ecol Prog Ser 118:215-227

Reyes E, Merino M (1991) Diel dissolved oxygen dynamics and eutrophication in a shallow, well-mixed tropical lagoon (Cancun, Mexico). Estuaries 14:372-381

Risgaard-Petersen N, Rysgaard S, Nielsen LP, Revsbech NP (1994) Diurnal variation of denitrification and nitrification 
in sediments colonized by benthic microphytes. Limnol Oceanogr 39:573-579

Rizzo WM, Lackey GJ, Christian RR (1992) Significance of euphotic, subtidal sediments to oxygen and nutrient cycling in a temperate estuary. Mar Ecol Prog Ser 86: $51-61$

Rizzo WM, Dailey SK, Lackey GJ, Christian RR, Berry BE, Wetzel RL (1996) A metabolism-based trophic index for comparing ecological values of shallow-water sediment habitats. Estuaries 19:247-256

Sfriso A, Pavoni B, Marcomini A, Orio, AA (1992) Macroalgae, nutrient cycles, and pollutants in the Lagoon of Venice. Estuaries 15:517-528

Shoaf WT, Lium BW (1976) Improved extraction of chlorophyll $\mathrm{a}$ and $\mathrm{b}$ from algae using dimethylsulfoxide. Limnol Oceanogr 21:926-928

Sundbäck K, Jönsson B, Nilsson P, Lindström I (1990) Impact of accumulating drifting macroalgae on a shallow-water sediment system: an experimental study. Mar Ecol Prog Ser 58:261-274

Sundbäck K, Carlson L, Nilsson C, Jonsson B, Wulff A, Odmark S (1996) Response of benthic microbial mats to drifting green algal mats. Aquat Microb Ecol 10: 195-208

Sundbäck K, Miles A, Göransson E (2000) Nitrogen fluxes,

Editorial responsibility: Kenneth Heck (Contributing Editor), Dauphin Island, Alabama, USA denitrification and the role of microphytobenthos in microtidal shallow-water sediments: an annual study. Mar Ecol Prog Ser 200:59-76

Thybo-Christesen M, Blackburn TH (1993) Internal Ncycling, measured by ${ }^{15} \mathrm{NH}_{4}{ }^{+}$dilution, in Cladophora sericea in a shallow Danish bay. Mar Ecol Prog Ser 100: $283-286$

Tyler AC, McGlathery KJ, Anderson IC (2001) Macroalgal mediation of dissolved organic nitrogen fluxes in a temperate coastal lagoon. Estuar Coast Shelf Sci (in press)

Valiela I, Foreman K, LaMontagne M, Hersh D, Costa J, Peckol P, DeMeo-Andreson B, D'Avanzo C, Babione M, Sham CH, Brawley J, Lajtha K (1992) Couplings of watersheds and coastal waters: sources and consequences of nutrient enrichment in Waquoit Bay, Massachusetts. Estuaries 15:443-457

Valiela I, McClelland J, Hauxwell J, Behr PJ, Hersh D, Foreman K (1997) Macroalgal blooms in shallow estuaries: controls and ecophysiological and ecosystem consequences. Limnol Oceanogr 42:1105-1118

Viaroli P, Bartoli M, Bondavalli C, Christian RR, Giordani G, Naldi M (1996) Macrophyte communities and their impact on benthic fluxes of oxygen, sulphide and nutrients in shallow eutrophic environments. Hydrobiologia 329: 105-119

Submitted: September 27, 2000; Accepted: March 12, 2001 Proofs received from author(s): June 8, 2001 